\title{
Application of Urban Geology in Construction Projects (Case Study: Urban Geology of Sarpol-e Zahab, Kermanshah Province, Iran)
}

\author{
Sajad Afzali ${ }^{\star}$, Faezeh Taheri Sarmad ${ }^{2}$, Mojtaba Heidari ${ }^{3}$ and Seyed Hossein Jalali ${ }^{4}$ \\ ${ }^{1}$ Department of Geology, Kermanshah Branch, Islamic Azad University, Kermanshah, Iran \\ ${ }^{2}$ Department of Architecture, Eslamabad-e-Gharb Branch,Islamic Azad University,Eslamabad-e-Gharb,Iran \\ ${ }^{3}$ Associate Professor, Department of Geology, Faculty of Sciences, Bu-Ali Sina University, Mahdieh Ave., Hamedan 65175-38695, \\ Iran \\ ${ }^{4}$ Ph.D.of Engineering Geology, Department of Geology, Faculty of Sciences, Bu-Ali Sina University, Mahdieh Ave., Hamedan \\ 65175-38695, Iran
}

Received: 2019-02-12 Accepted: 2021-03-10

\author{
Keywords: \\ Urban geology; \\ natural hazards; \\ earthquake; \\ Sarpol-e Zahab \\ Correspondent email: \\ sajadafzali@yahoo.com
}

\begin{abstract}
Urban geology is a preliminary study for the construction and development of cities, which has been more prominent in recent decades in some countries despite its long application history. It assesses the impact of geological and natural phenomena on urban space and available structures. The earthquake on Nov. 21, 2017, inflicted a lot of damage to the city of Sarpol-e Zahab, west of Iran, including financial losses and casualties. Reconstruction of this city and planning for its sustainable development entail conducting urban geological studies. In the present study, the effect of natural phenomena on Sarpol-e Zahab County was studied by investigating its geology and geomorphology. The results showed that, in addition to the earthquake that habitually affected the city of Sarpol-e Zahab, the hazards of other phenomena are also significant. Recorded horizontal acceleration in the recent earthquake confirmed the high seismicity of Sarpol-e Zahab has.
\end{abstract}

Q2021 by the authors. Licensee Indonesian Journal of Geography, Indonesia.

This article is an open access article distributed under the terms and conditions of the Creative Common

Attribution(CC BY NC) licensehttps://creativecommons.org/licenses/by-nc/4.0/.

\section{Introduction}

Statistical surveys show that during an 80-year period, the urbanization rate in Iran has increased by a factor of three and reached from $28 \%$ in 1921 to $68.77 \%$ in 2006 . Also, the number of cities in Iran increased from 199 in 1956 to 1016 in 2006. As a result, the demographic composition of the country's population changed from a mostly rural and nomadic status to an "urbanite majority". Although the rate of urbanization is different in various regions and provinces of Iran, almost all regions of the country are rapidly being urbanized and the occurrence of physical, marginalization, economic and social problems is increasing as a natural process (Sarvar, 2009).

The development of cities and the construction of new towns need the right land and study. In this respect, geological studies are used to determine the proper site for the construction of cities. Urban geology is one of the topics that has been increasingly put into practice for a long time (Ami, 1900). In summary, urban geology focuses on monitoring by using remote sensing data, mapping, and modeling; and geohazards in the urban environment. Sustainable planning covers communication (with planners), use of the subsurface, planning in rural areas, ground and surface water risks for planners, and the relationship between planning and risk management. Landscape exploitation is concerned with mineral extraction, groundwater exploitation, and, particularly, safety problems attributed to the extraction of asbestos-bearing rocks. This is a varied range of topics, but they are all important to ensure the wellplanned, sustainable and imaginative development of the areas where most of the world's people live (Lollino et al., 2015).

In the 1960 s and 70s, some researchers (McGill, 1964; Price, 1971; Harrison, 1975) came up with urban geology. In 1974, Matthewson and Font introduced earth science studies that were neglected in the design process of cities. In recent years, scattered studies on urban geology have been conducted around the world (e.g., Legget, 1980; Brennand, 1998; Bélanger \& Moore, 1999; Bridge et al., 2005; Bathrellos, 2007; Pantelias et al., 2008; El May al., 2010; Culshaw \& Price, 2011; Marschalko et al., 2013; Lollino et al., 2015; De Mulder, 2015; Donovan, 2018).

The city of Sarpol-e Zahab has a population of about 81,000 people in the west of Kermanshah province (amar.org.ir), Iran. The recent earthquake on November 12, 2017, inflicted the most severe financial and human damages among all the earthquake-struck areas, wherein 508 people died and the financial loss was estimated at a value more than 100 million dollars (www.farsnews.com). Nevertheless, there is a need for more studies in urban areas (e.g., Sarpol-e Zahab, which has been damaged by these phenomena) on the reconstruction and long-term development stages.

In this study, the geological and geomorphologic characteristics affecting the development of the Sarpol-e Zahab County are studied. Furthermore, the vulnerability of 
the county to some natural hazards is investigated. Some other geotechnical phenomena (such as site effects and liquefaction) affecting the county are also evaluated as well.

\section{Method}

The geomorphology of the study area was examined using previous studies. Then, maps and satellite images were used to study the geomorphological phenomena of the area. A geological map of the area (NIOC) on the scale of $1 / 50000$ was used to study the geology and draw the geological map of the study area. By studying the maps, the geological structures of the region such as folds and faults were recognized by studying the maps. These structures were thoroughly studied to investigate their impact on the city of Sarpol-e Zahab. At this stage, past studies were assessed and data were gathered to estimate the seismicity of the region. Meteorological and flood data were prepared from the Meteorological Organization and Regional Water Organization of Kermanshah province, respectively. Eighteen boreholes from Iran Geotechnical Database (http:// geotech.bhrc.ac.ir) have been investigated to determine the geotechnical characteristics of the Sarpol-e Zahab city site.

\section{Geological setting}

Different divisions of Zagros have been presented by Alavi (1994), Berberian (1995), and others. In the newest division, the Zagros mountains from the northeast to the southwest are divided into several major parts, including high Zagros, Folded Zagros, Dezful embayment and Zagros foredeep regions, and the northern border of Saudi Arabia platform. These structural zones are separated by important faults, For instance, the boundary between the high Zagros and the simply folded Zagros is a fault called the Zagros main reverse fault. This fault is located at the northern margin of the studied region. Also, The boundary between the folded Zagros structural zone and Dezful embayment is also a fault called the Balarud fault, which is a part of the mountain front fault. The Balarud fault is covered with Cenozoic sediments in most places. This fault can be seen at the northern and southern margins of the Gurpi anticline. The study area is located at the western part of simply folded Zagros structural zone in the west of Iran within a 15-km distance from the Iraq border (Fig. 1). The geological map and lithology of all existing rock units in the region are presented in Fig. 2.

\section{Geomorphology}

The Sarpol-e Zahab County, located between $45^{\circ} 43^{\prime}$ and $46^{\circ} 10^{\prime} \mathrm{E}$ and $34^{\circ} 11^{\prime}$ and $34^{\circ} 41^{\prime} \mathrm{N}$, is one of the cities of Kermanshah province. Different rocks under various climatic conditions have different resistances (Viles, 2013), and thus one of the determinants of geomorphology is rock and its hardness. Erosion in carbonate units occures in dissolution and physical crushing, which results in the formation of karstic springs and tafoni landscapes. The Sarpol-e Zahab County is located in the highly folded structural zone wherein the axes of many folds are close to each other. Some folds are severely eroded and the fold axes are highly elongated.

There is a close relationship between the erosion, topography, and rock types. The limestone is formed at high altitudes, cliffs, and high ridges and the Asmari formation has become a hard formation. Also, Gurpi, Pabdeh and Gachsaran formations are soft units.

From a morphological point of view, the region has different units of mountain and plain, which are directly linked to the geological structures of the region. Hence, their trend is aligned with the general trend of the structures of the region. Anticlines often form long points and mountains in

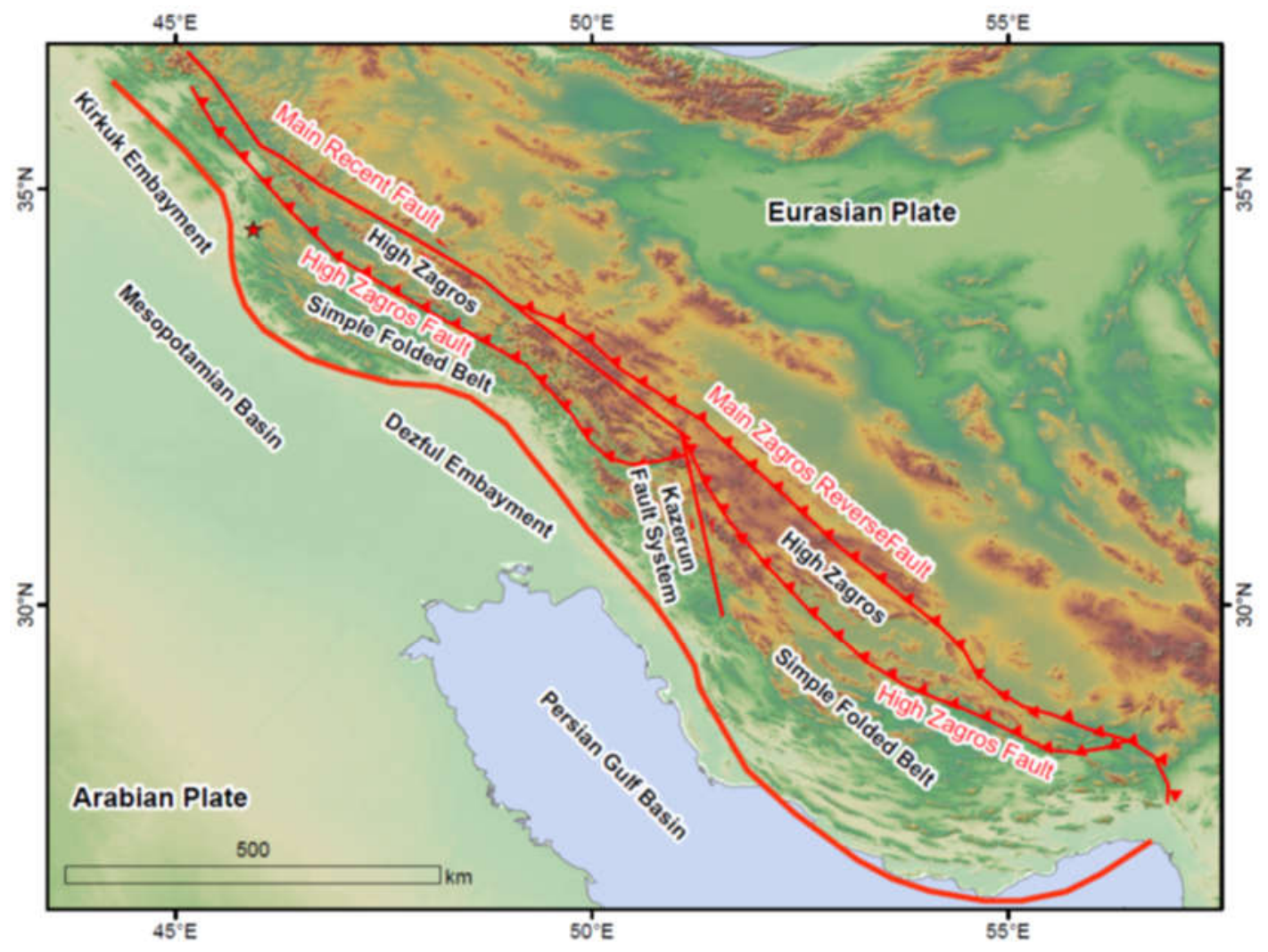

Figure1. The structural position of the studied area in the Zagros Mountains (Berberian, 1995) 

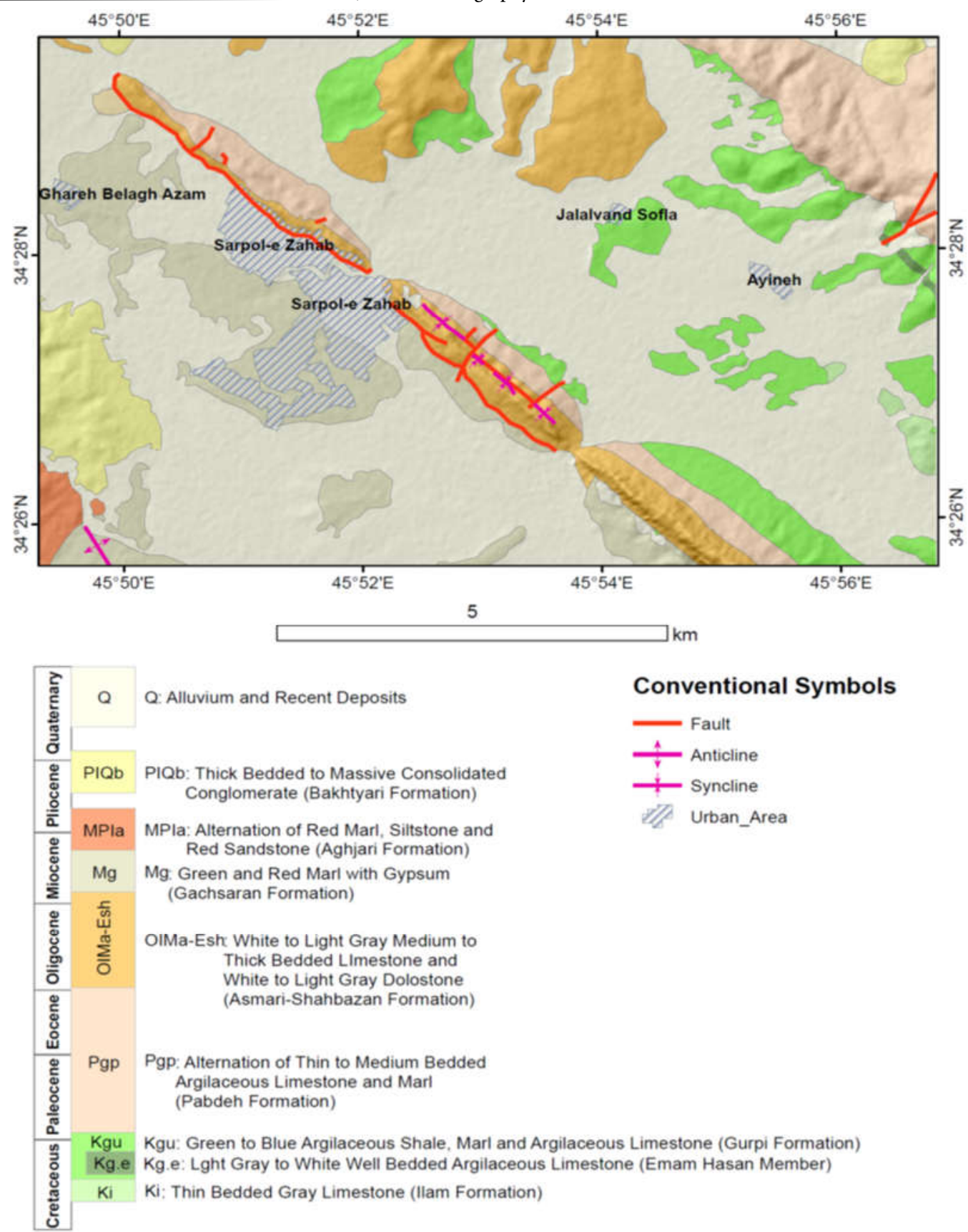

Figure 2. Geological map of the study area (NIOC, 2013, with modifications)

the area. The cores of the synclines are often covered with alluvium and seen as synclinal valleys and plains. Two longtailed, synclinal valleys are seen in the north and south of the Sarpol-e Zahab area (Figure 2).

\section{Topography}

This area of Kermanshah province has rough topography and high altitude and is a region with many permanent springs and rivers. The important highlands in this region include Mount Zangalian in the northeast, the MianKal and Braza Mounts in the southeast of Patagh, the Danekhoshk Mountain along the Danekhoshk anticline, the Bazideraz Mountain parallel to the northern edge of the Imam Hassan anticline, the Sarkesh, Talesorkh, and Sonboleh Mountains in the southwest. Zangalian and Braza Mountains with elevations over 1400 meters are the highest points in the area.

The Sarpol-e Zahab County consists of semi-high and long mountains, extending from the northwest to the southeast. These heights are separated from each other by long valleys where the most important plains in the area are located, and the main population centers and existing paths are in line with the above morphology. The foothills areas of the region mainly include the middle parts of the Sarpol-e Zahab County. In addition, among the mountainous areas of the region, there are several plains, including Zahab plain, Dayrah plain in the south of Sarpol-e Zahab city, and Sarghalamdar plain in the northwest of this city. The dominant heights of the plains are less than 500 meters. In terms of topography, the study area is located in mountains, foothills, and plains.

\section{Seismotectonic and important faults}

The structural position of the study area is located in the Zagros Mountains considered to be the most active and seismic zone in Iran. Earthquakes of small to medium magnitudes occur on most occasions, and large Zagros earthquakes have often occurred at parts of the main recent 
fault of Zagros, which is a strike-slip right-lateral fault system (Zamani \& Agh-Atabai, 2011). The Zagros folded-thrusted belt extends about $1,500 \mathrm{~km}$ from the Taurus Mountains in the south-east of Turkey to the Minab fault in the east of the Strait of Hormuz in southern Iran. The main Zagros reverse fault and the main recent fault of Zagros are the most important fault systems of this state. The main Zagros reverse fault extends from the west of Iran to the Minab fault, Also, the main recent fault of Zagros is almost parallel to the main Zagros reverse fault, and in several places intersect it. The main recent fault of Zagros extends from the Iran-Iraq border and Marivan to the southeast of Iran.

Zagros earthquakes are shallow and usually occur at a depth of 8 to 15 kilometers of the earth's crust. The main propulsion force inducing earthquakes in Iran, particularly Zagros, is a result of the Saudi Arabia movement towards Eurasia estimated at around 10 millimeters per year in the Zagros range with GPS measurements. Among the destructive earthquakes in this area, the 1909 Silakhor destructive earthquake with a magnitude of $7.4 \mathrm{Ms}$ could be regarded as the largest recorded earthquake with 45 kilometers of the surface fissure (BHRC, 2017).

\section{Seismicity}

One of the most important sources available for studying the seismicity of each seismic state is the historical earthquakes in the area. Historical earthquakes are referred as to the pre-twentieth century earthquakes (before 1900) when seismic networks did not expand, and ground motion data was obtained from historical texts such as historical books, travelogue, and sometimes oral speeches. It is evident that these sources provide little awareness of the strong motion epicenter. As already mentioned, these earthquakes do not have a precise location, although the epicenter of occurrence, which is very important for its historical seismicity can be determined with an error of at least $30 \mathrm{~km}$ depending on historical sources. The study area has been prone to these earthquakes and the locations of historical earthquakes can be specified using previous works (e.g, Ambraseys \& Melville (1991). The approximate epicenter of these earthquakes are shown in Figure. 3. The earthquake event list has been collected regarding the tectonic seismic situation in the study area. Instrumental earthquakes in Kermanshah province and adjoining areas (1900 to 2017) are presented in Fig. 4. The earthquakes that occurred from Apr. 1, 2017, to Nov. 22, 2017 have been plotted in Figure 5.

\section{Geotechnical issues}

Geotechnical properties

Eighteen boreholes from Iran Geotechnical Database have been investigated to determine the geotechnical characteristics of the Sarpol-e Zahab city site. These boreholes are located at four project sites, shown in Fig. 6. Based on the conducted tests at different depths, the SPT number of the ground at 30 meters averaged around 26. According to the results of gradation, liquid limit, plastic limit, and the Unified classification of soil, that was performed over samples taken at different depths of the boreholes, it can be concluded that the layers identified in the borehole fall mainly into the category of low plasticity clay soils (CL) that has been changed to poorly graded clayey gravel (GP-GC) at a deeper level (deeper than 20 meters). The shear wave velocity (Vs) should be measured in underlying layers to specify the ground type. Nevertheless, due to the lack of this test, experimental relations were used to determine shear wave velocity. In this regard, one of the most valid and applicable relationships is the Seed-Idriss relationship, which is expressed as follows:

$$
V_{s}=200 \mathrm{~N}^{0.5}(\mathrm{ft} / \mathrm{Sec})
$$

According to the average SPT value of 26 at 1-30 m, shear wave velocity is obtained of $310 \mathrm{~m} / \mathrm{Sec}$. Accordingly, given the condition of the underground layers, the ground of the city matched with the type III of ISIRI 2800 standard. The

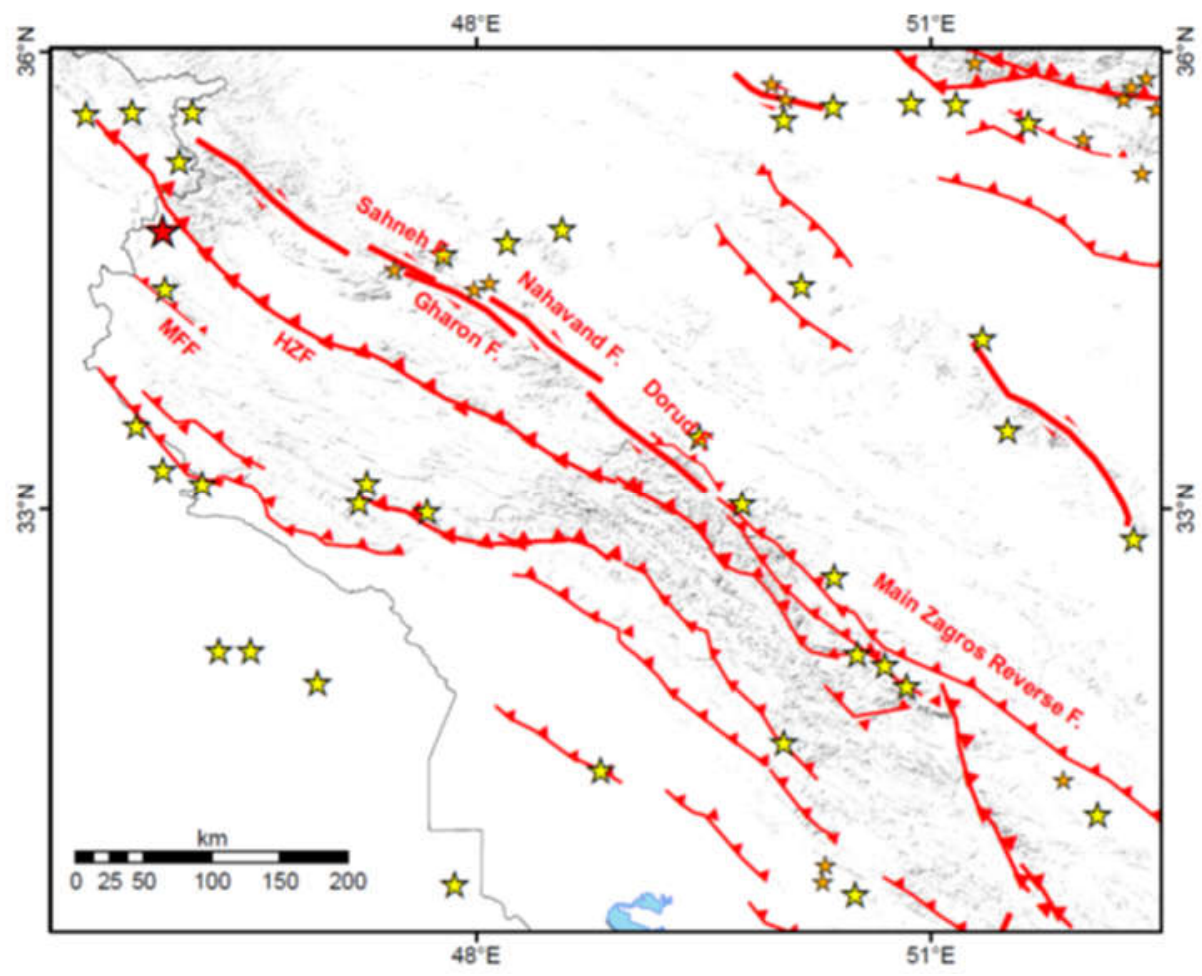

Figure 3. Yellow stars and a red star, respectively designate historical earthquakes occurring in the study area and the main new earthquake 

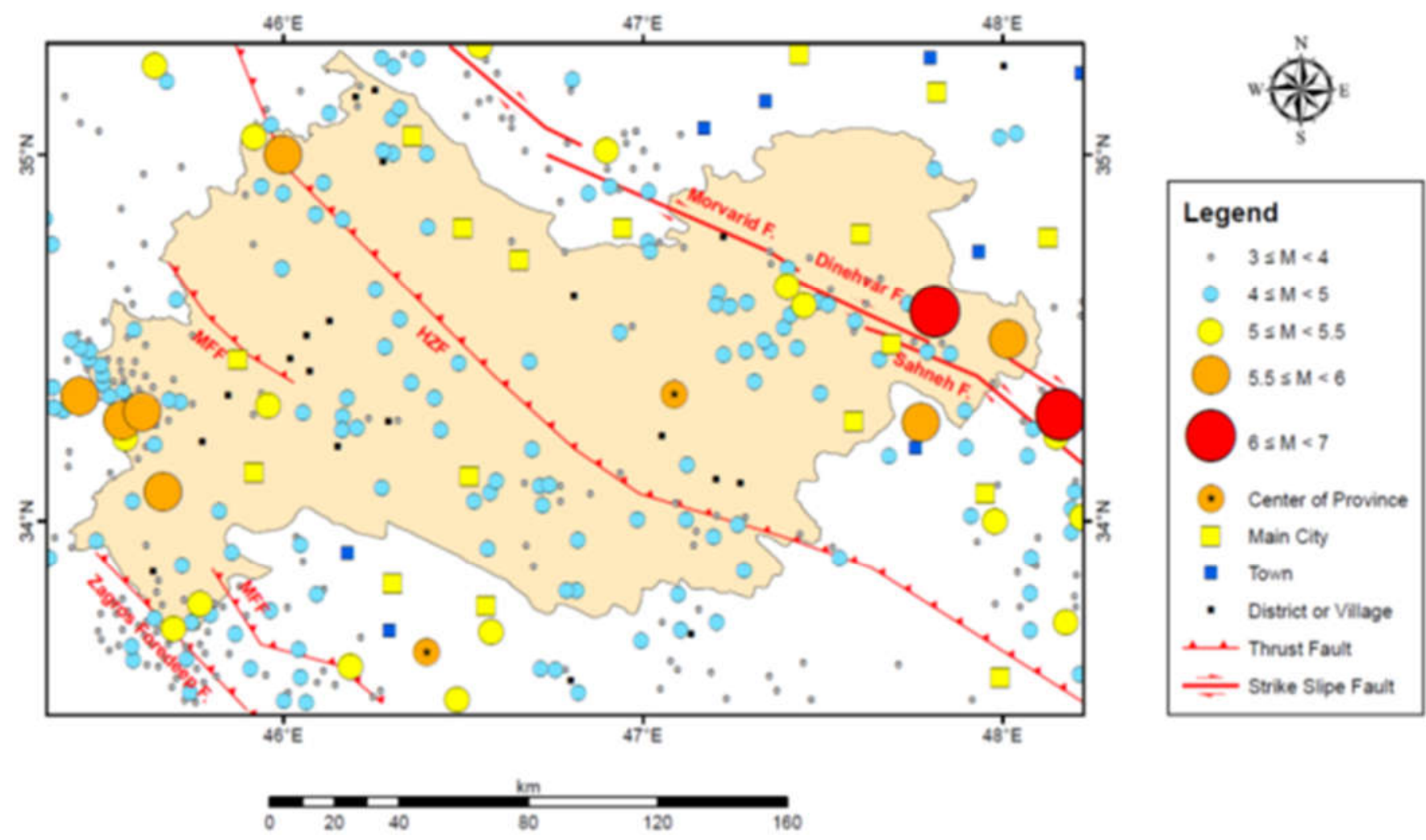

Figure 4. Instrumental earthquakes in Kermanshah province and adjoining areas (1900 to 2017)

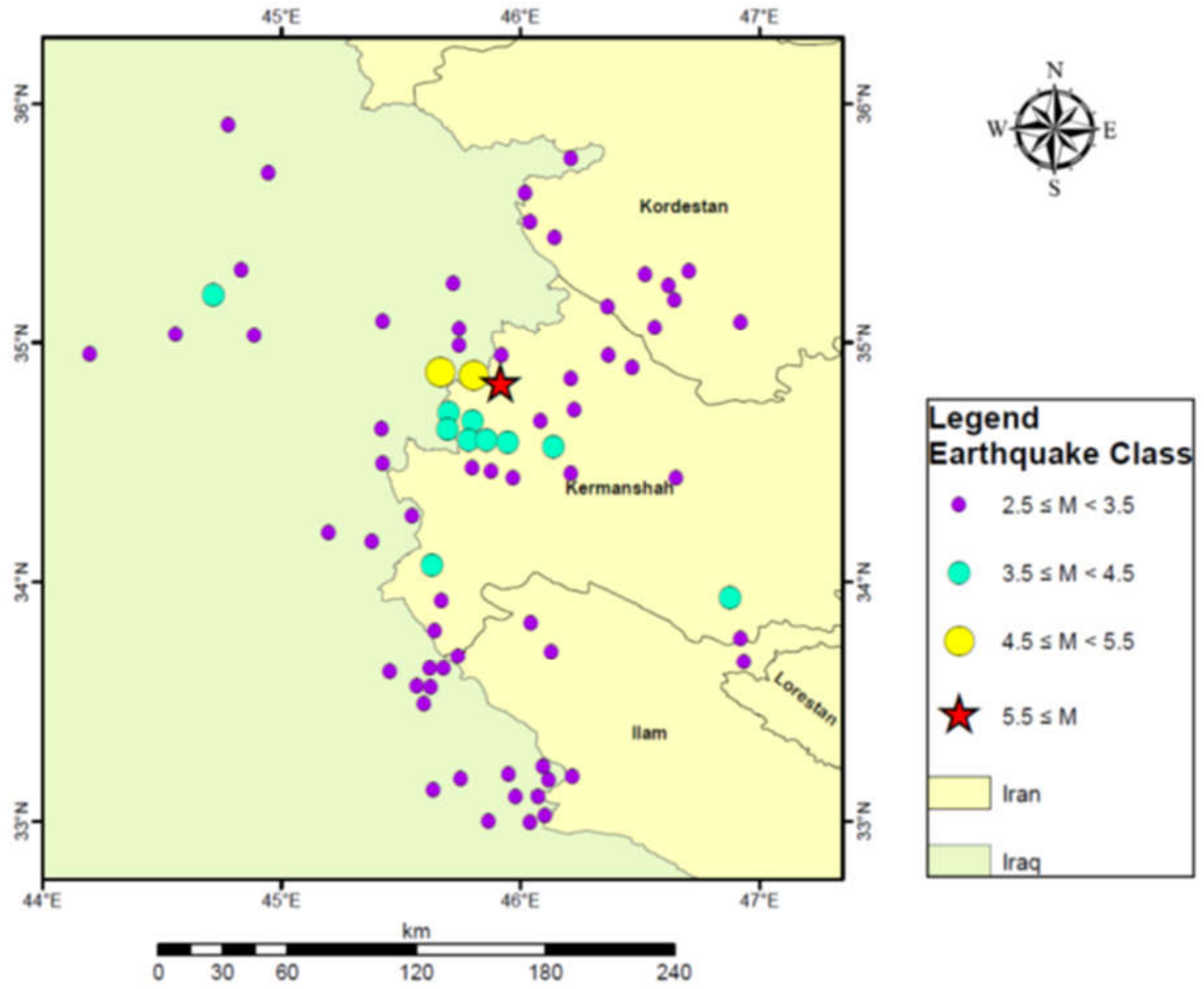

Figure 5. Occurred earthquake map in the region from Apr. 1, 2017, to Nov. 22, 2017 


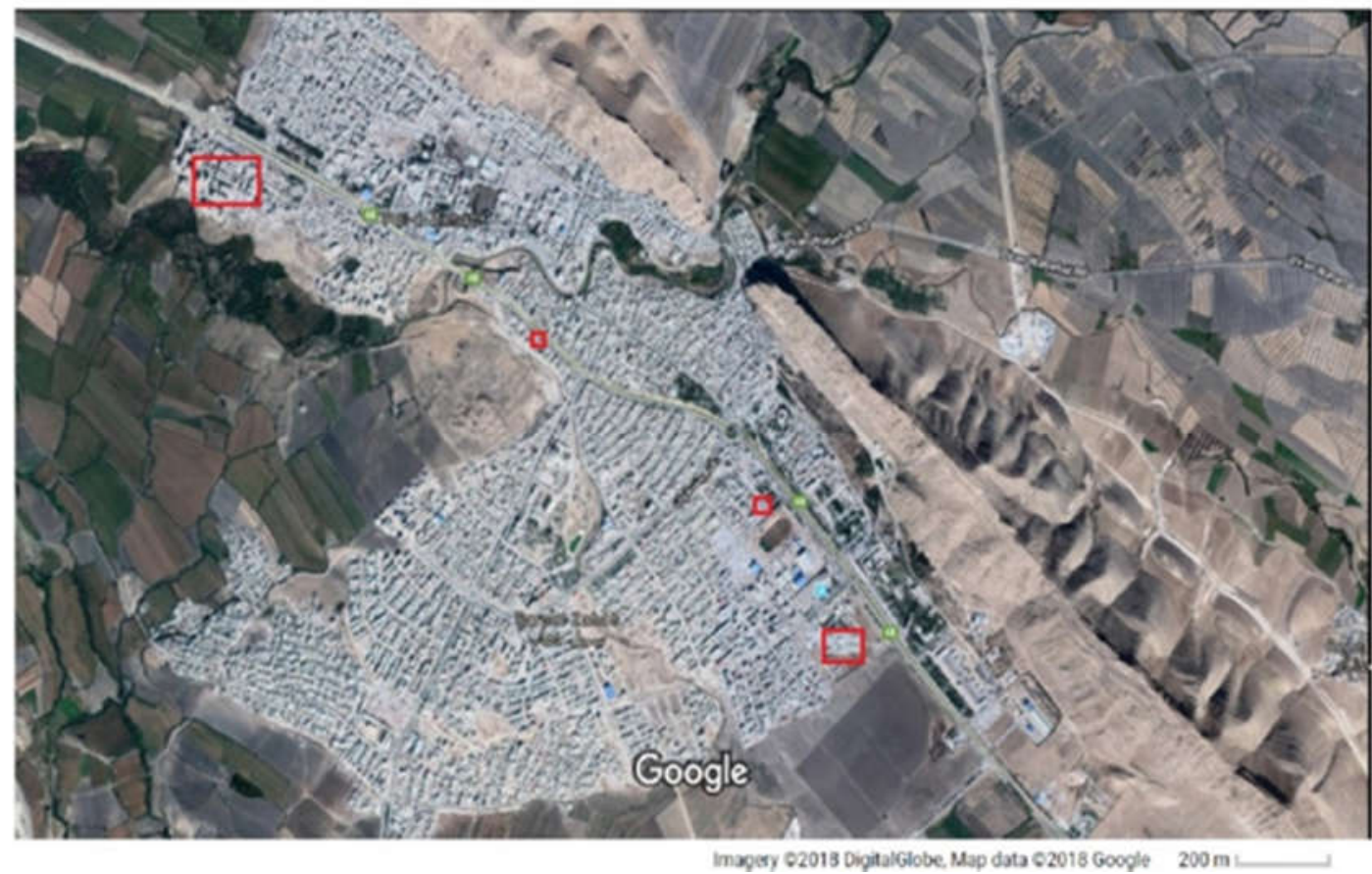

Figure 6. Location of the studied boreholes at the city of Sarpol-e Zahab

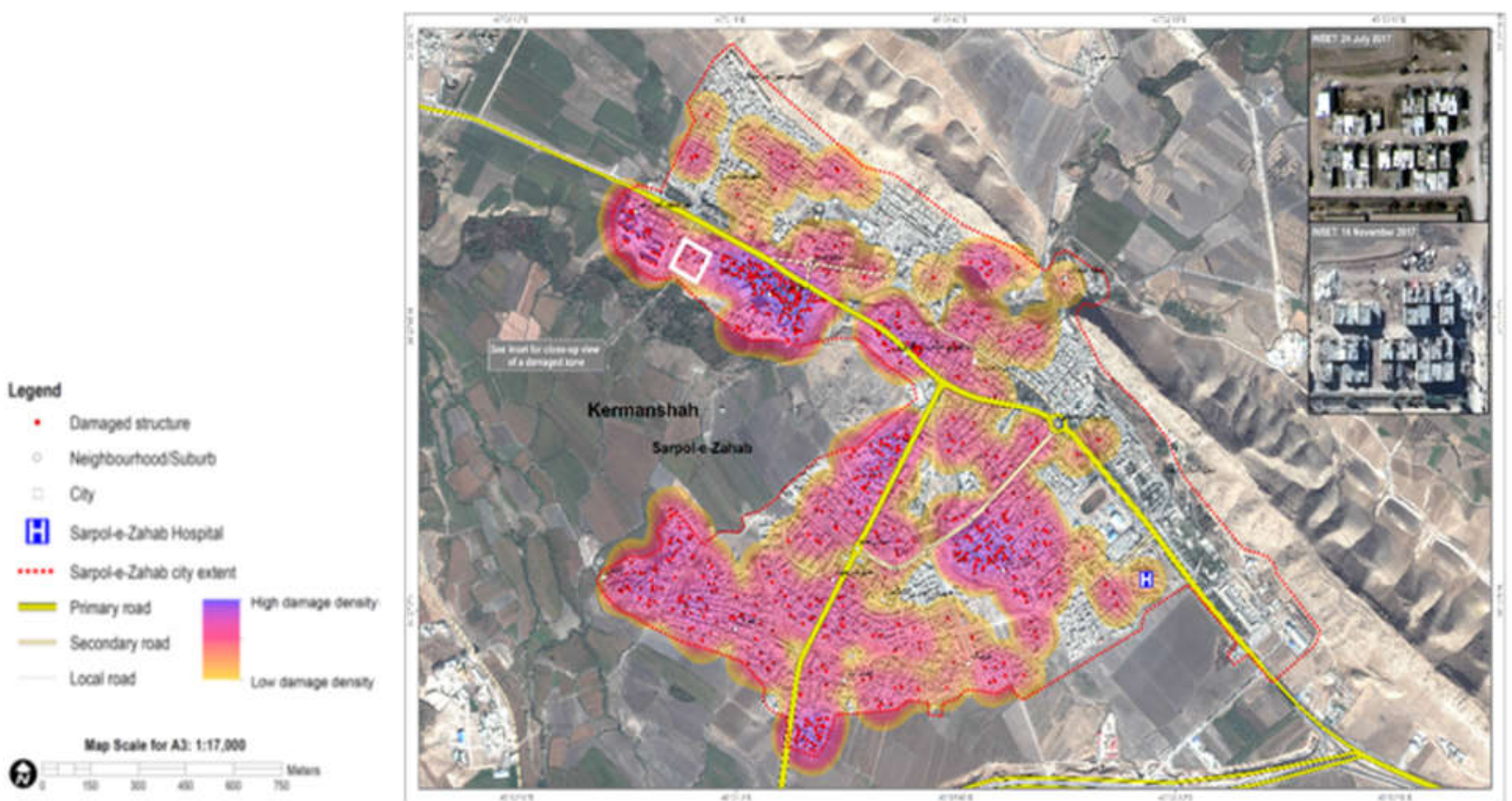

Figure 7. Damaged structures and related density map in Sarpol-e-Zahab (unitar.org)

average dry unit weight of soils in the area is about $1.67 \mathrm{gr} /$ $\mathrm{cm} 3$, indicating the medium density of soil. The water table has been observed only in two boreholes at depths of 2 and 8.5 meters, and other boreholes have not had water table.

\section{Site effects}

Damaged structures and related density map in Sarpol-eZahab is shown in Fig. 7. The distribution of damages in the city of Sarpol-e Zahab is not uniform and significantly varies in different parts of the city, even though the similarity of the structure types has been conisdered. There are two distinctly different trends of damages in the city, namely the northern parts of the main boulevard of the city (Karbala Boulevard) with negligible damages and the southern parts of this boulevard with severe damages. The frequency distribution map and the magnification values obtained from the environmental vibrations are shown in Figure 8.

Liquefaction and sand boiling

Liquefaction phenomenon and sand boiling occurred in the riverbed of a river adjacent to the city of Sarpol-e Zahab , especially in the Shahid Shiroudi Mehr complex and Foladi areas. The effects of this phenomenon on the riverbed are well illustrated in Figure 9.

The ground deformation that occurred in the Foladi district- Shahid Shiroodi Mehr housing complex can be seen in Figure 10. 

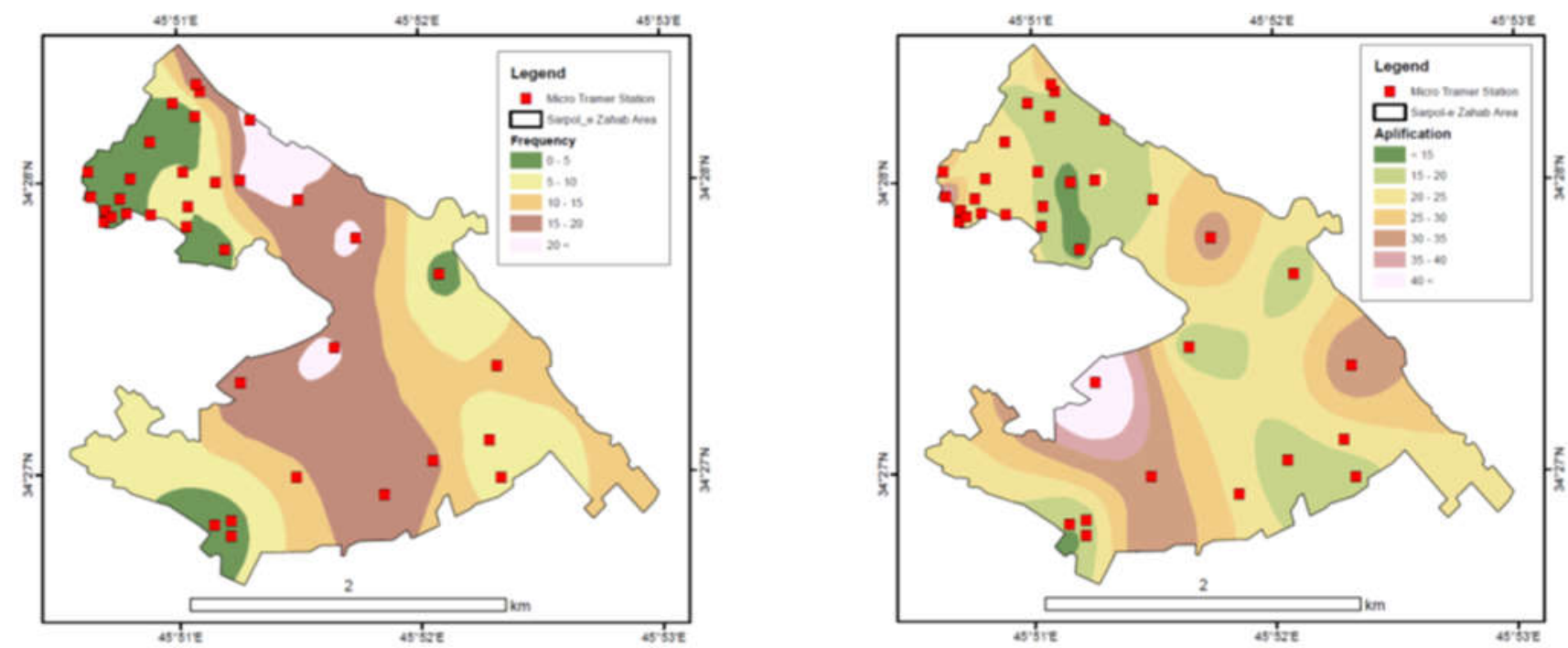

Figure 8. a) The site natural frequency distribution map; and b) the magnification values obtained from the environmental vibrations (IIEES, 2017)
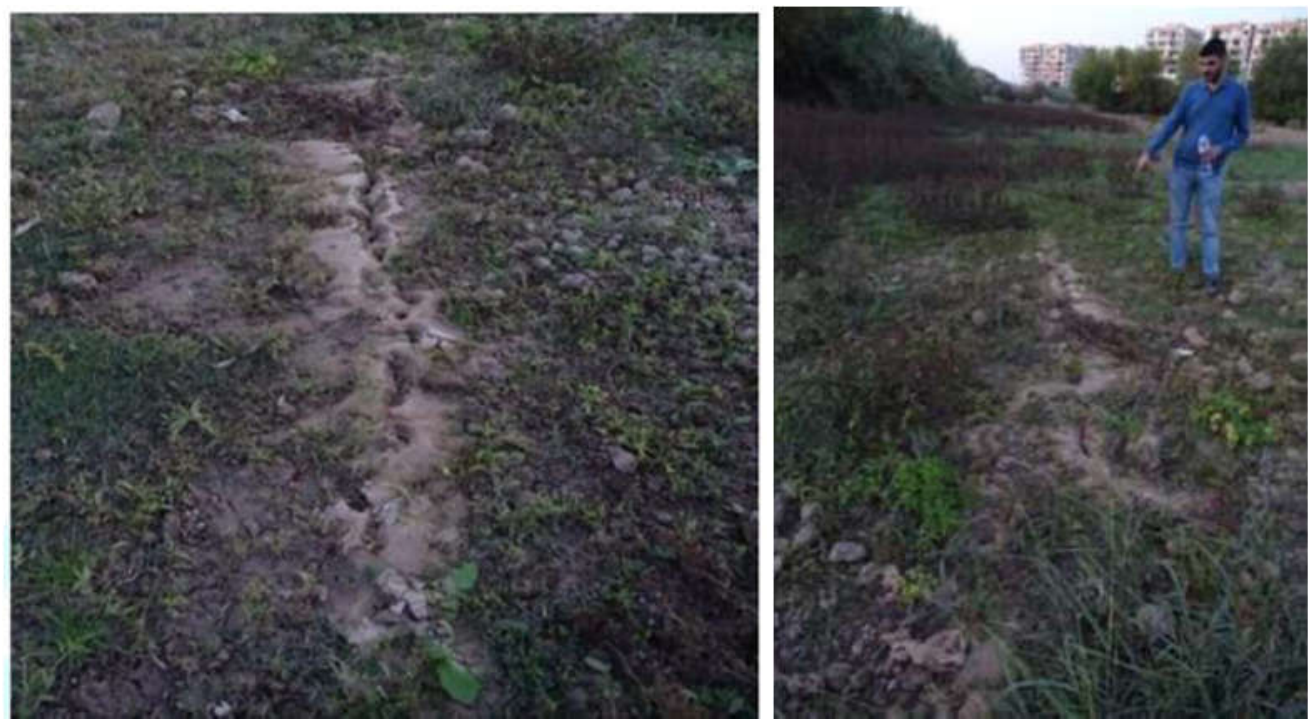

Figure 9. Images of the liquefaction phenomenon and sand boiling in different parts of the riverbed near Shahid Shiroodi Mehr housing complex (IIEES, 2017).
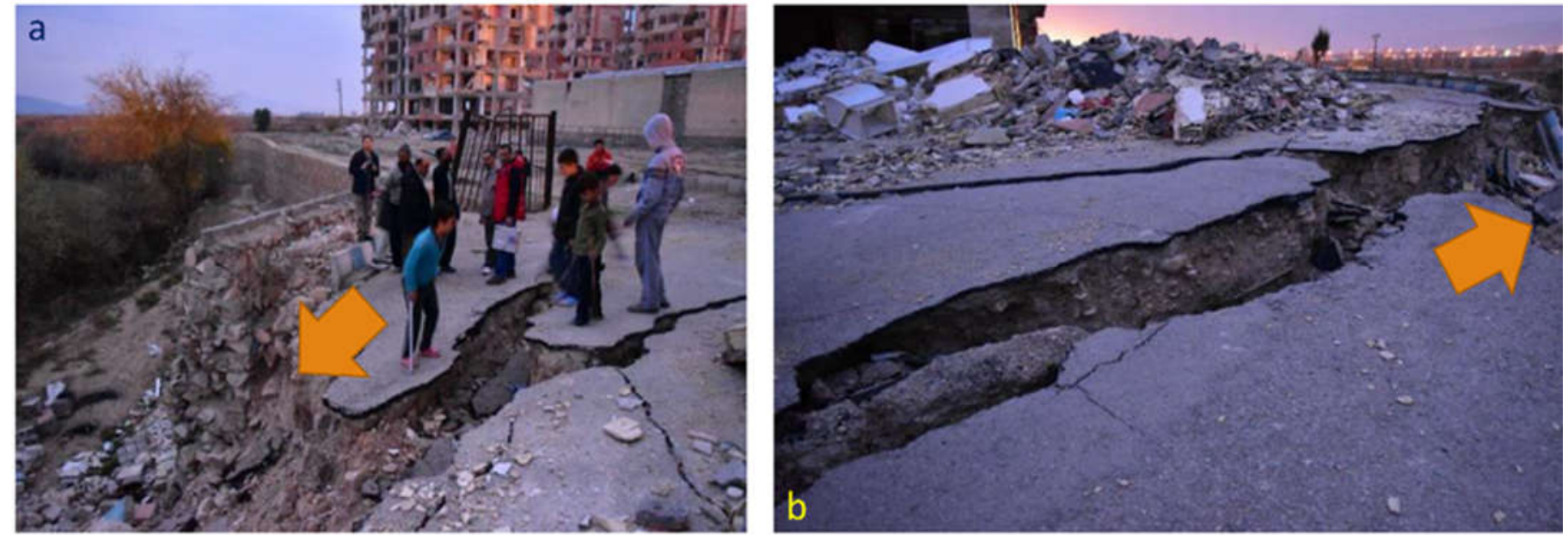

Figure 10. Ground deformation in a) Shahid Shiroodi Mehr housing complex, and b) Foladi District (Miyajima et al. 2018). 


\section{Result and Discussion}

The study area is located in a special geological situation which contains simply folded Zagros structural zone specifications such as several folded layers and very crashed crust with many major and small faults (Fig. 1). This geological setting causes the suitability for some natural hazards such as earthquake to occur. The geomorphology of the region is very interesting owing to the special geological setting which is stated as follows. Several interval mountains and plains are repeated in this area. Also, anticlines and synclines often form heights and plains in the area, respectively. The cores of the synclines are often covered with alluvium and seen as synclinal valleys and plains. Within the Sarpol-e Zahab area, two long-tailed, synclinal valleys are seen in the north and south (Figure 2), wherein the deposit's thickness is commonly decreasing toward heights.

Historical earthquakes mapping in this region indicates its past seismicity. Eighty-four historical earthquakes occurred in the studied area which confirms high seismic activity of the area. On the other hand, by studying instrumental earthquakes, as well as historical earthquakes, a large earthquake could be expected in this fault zone. After the events that has occurred in the region since 2006, about 1043 earthquakes of magnitude greater than 2.5 Richter have been recorded by the Iranian Seismological Center (Fig. 4). A total of 124 earthquakes occurred in the region from the beginning of 2017 to November 23, 2017 (Figure 5), and the highest number of earthquakes occurred in November. In the past month, 61 earthquakes have been recorded with the magnitudes of higher than 2.5 on the Richter scale, revealing that the study area is located in a highly seismic reign.

The distribution map of the maximum acceleration recorded by the interpolation method at the accelerograph stations of the Road, Housing \& Urban Development Research Center showed the highest acceleration of $681 \mathrm{~cm} / \mathrm{s}^{2}$ at the Sarpol- e Zahab station, which was reduced by a factor of two $\left(300 \mathrm{~cm} / \mathrm{s}^{2}\right)$ in the Goorsefid. Given the distance between this station and the earthquake epicenter, this difference seems strange and raises the possibility of a particular phenomenon at this station. The presence of velocity pulse, which usually occurs near fault field, is quite clear in the velocity time history of the Sarpol-e Zahab station. This phenomenon, known as the "Directivity Pulse", occurred due to the alignment of faulting with the direction of slipping at the fault surface towards the Sarpol-e Zahab station, which increased the maximum acceleration at this station to be more than twice the maximum acceleration at other stations at the similar distance. As a result, there was more severe damage around this station, i.e., in the city of Sarpol- e Zahab and suburban townships and villages. This phenomenon is one of the index effects of the fault source in the near-fault field, re-emphasizing on the importance of recognizing the faulting process to better understand the maximum acceleration and its dispersion in the region (IIEES, 2017).

As regards the distribution of damages in the city of Sarpol-e Zahab, other than the problem of Directivity, the impacts of site conditions have also intensified the damages in the city of Sarpol-e Zahab. From the geological point of view, this city is located on the syncline with a northwestsoutheast trend. The northern edge of this syncline is called the Miankal Mountain, and the Alvand River passes through the city by cutting off this mountain. Most of the city's areas, especially on the southern side of the main boulevard, have been built on the predominantly fine-grained deposits of this river.

The thickness of these deposits increases toward the thalweg by getting away from northern altitudes, which seems amplified ground motion in these areas and caused severe destruction. Also, in areas in the southern part of Sarpol-e Zahab main boulevard, one needs to address the presumption of the existence of man-made ground in some areas (e.g., the Foladi area) as well as piling the post-war construction debris and construction on them, as the amplification of the above-mentioned soils and further damages.

As can be observed in the frequency distribution map (Figure 8), at the western end of the city, the results of the study obtained by the horizontal-to-vertical spectral ratio method present a certain decreasing trend of the natural frequency by getting away from the northern heights. In this regard, in the north of the Sadra town which has been founded on a rock, a peak with the frequency of $25 \mathrm{~Hz}$ is observed on the $\mathrm{H} / \mathrm{V}$ curves, whereas the curve is flat for lower frequencies, which represents the rocky site. The amplification frequency has been suddenly reduced to $5 \mathrm{~Hz}$ at a little distance from this place toward the south. This trend continued towards the Shahid Shirodi Mehr complex, aside from the fact that the range of resonance frequency decreased again from 5.8 to $2 \mathrm{~Hz}$ at different locations near the Shahid Shirodi Mehr complex approaching the river. Accordingly, one can conclude that the main part of the city that constructed on Alvand River deposits is more probable to effect strong ground motion waves which, in turn, increase the damages doubly.

As regards the numerous fractures observed in the beds of the Shahid Shiroodi Mehr housing complex, it seems that the occurrence of this phenomenon in the depth of sediments under the site of these buildings has led to lateral extensions and numerous fractures in this district (Fig. 10). It is likely that this ground deformation appeared due to liquefaction occurrence in the subsoil layer.

Large ground deformation was also found in the Foladi district- Shahid Shiroodi Mehr housing complex, which was located within the city of Sarpol-e Zahab. This significant ground deformation was most likely induced by liquefaction at the time of the earthquake, which caused the ground surface to move downward. This area is very prone to liquefaction since there is a river flowing in this area. According to the information from the inhabitants, before the earthquake occurred, the government of Sarpol-e Zahab City had planned to relocate residents who lived in this area due to high groundwater levels here (Miyajima et al., 2018).

\section{Conclusions}

Major studies such as urban geology are vital to rebuilding and planning the sustainable development of the Sarpol-e Zahab city, which has suffered the most damage due to the recent earthquake. This study investigated geology, geomorphology, and geotechnical factors, which controlled the city ground behavior. Moreover, the impact of natural hazards on the city of Sarpol- e Zahab has been evaluated.

The city of Sarpol-e Zahab has been constructed on the recently deposited sediments (by Alvand River) in the valley between two heights of the area. The thickness of these sediments has decreased from the riverbed to the city's 
heights so that the structures of the north-eastern part of the city are mainly constructed on rocky sites. This seems to be due to the site effects on the ground strong motion a major cause of the less damage in the northern parts of the city in the recent earthquake.

A large difference in the maximum horizontal acceleration between Sarpol-e Zahab and Goorsefid stations is one of the index effects of the fault source in the near-fault field, implying the significance of recognizing the faulting process to better specify the maximum acceleration and its dispersion in the region.

The study of the historical and instrumental earthquakes in the study area, as well as recent earthquake events, has indicated high seismicity of the region. The recorded maximum horizontal acceleration of up to $681 \mathrm{~cm} / \mathrm{s}^{2}$ in the Sarpol-e Zahab station is another evidence of high seismicity of the region.

The risk of the liquefaction phenomenon should be considered in the sites near the main bed of the Alvand River, due to the extistance of sandy layers and layers prone to liquefaction in some boreholes, as well as the available evidence of liquefaction in recent earthquakes.

According to the results, the city of Sarpol-e Zahab is exposed to natural hazards such as earthquake and destructive phenomena including liquefaction and site effects. This calls more attention to geological issues in planning for sustainable development of this city.

\section{Acknowledgments}

This paper is a collaborative research project by authors in the Islamic Azad University, Kermanshah Branch. The authors gratefully acknowledge the Islamic Azad University, Kermanshah Branch, for their logistic and financial support.

\section{References}

Alavi, M. (1994). Tectonics of the Zagros orogenic belt of Iran: new data and interpretations. Tectonophysics, 239, 211-238.

Ambraseys, N.N. and C.P. Melville (1982). A History of Persian Earthquakes. New York: Cambridge University Press.

Ami, H.M. (1900). On the geology of the principal cities in eastern Canada: Royal Society of Canada, Transactions, 2nd Series, VI: section VI, 125-164.

Bathrellos, G. (2007). An Overview in Urban Geology and Urban Geomorphology. Bulletin of Geological Society of Greece, 40, 1354-1364. https://doi.org/10.12681/bgsg. 16888

Belanger, J.R. and C.W. Moore (1999). The use and value of urban geology in Canada: A case study in the National Capital Region. Geoscience Canada, 26(3), 121-129.

Berberian, M. (1995). Master blind thrust faults hidden under the Zagros folds: active basement tectonics and surface morphotectonics. Tectonophysics, 241, 193-224.

Brennand, T.A. (1998). Urban Geology Note: Oshawa Ontario. In P.F. Karrow, and O. L. White (Eds.), Geological Association of Canada, Special Paper 42: Urban Geology of Canadian Cities, 353-364.

Bridge, D., E. Hough, H. Kessler, S. Price, and H. Reeves (2005). Urban Geology: Integrating Surface and Sub-Surface Geoscientific Information for Development Needs. In: Ostaficzuk, S.R. (eds) The Current Role of Geological Mapping in Geosciences. NATO Science Series (Series IV: Earth and Environmental Sciences), 56, Springer, Dordrecht.

Culshaw, M.G., and S.J. Price (2011). The 2010 Hans Cloos lecture: the contribution of urban geology to the development, regeneration and conservation of cities. Bulletin of Engineering Geology and Environment, 70(3), 333-376. https:// doi.org/10.1007/s10064-011-0377-4

De Mulder, E.F.J. (2015). Communicating Applied Geoscientific Expertise to Rural and Urban Planners: Some Lessons Learned. In: Lollino, G., Manconi, A., Guzzetti, F., Culshaw, M., Bobrowsky, P., Luino, F. (eds) Engineering Geology for Society and Territory - Volume 5. Springer, Cham

Donovan, S.K. (2018). Using urban geology: a field guide to Morpeth Railway Station, northern England. Geology Today, 34(3), 97-99.

El May, M., M. Dlala, and I. Chenini (2010). Urban geological mapping: Geotechnical data analysis for rational development planning. Engineering Geology, 116(1-2), 129-138.

Farzanegan, E., M. Pourmohammad Shahvar, A. Eshaghi, M. Mirsanjari, H. Abdollahi, and H. Mirzaee Alavijeh (2017). Report of the November 12, 2017 Sarpol-e Zahab, Kermanshah Province earthquake. Road, Housing and Urban Development Research Center (BHRC), Iran Strong Motion Network.

Harrison, J.E. (1975). The Ottawa-Hull Urban Geology Project. 28th Canadian Geotechnical Conference, Canadian Geotechnical Society (pp. 9-16), Montreal, Canada

Institute of Standards and Industrial Research of IRAN, ISIRI. (2007). Seismic resistant design of buildings - Code of practice, standard No: 2800, 3st.revision (in Persian).

Internet 1: http://www.amar.org.ir/Portals/2/PropertyAgent/1428/ Files/1483/05.xls (14.12.2017)

Internet 2: The BHRC http://geotech.bhrc.ac.ir (06.07.2018)

Internet 3: The Kermanshah province regional water company http://www.kshrw.ir (04.12.2017)

Internet 4: The Kermanshah province regional meteorological office http:/www.kermanshahmet.ir (22.01.2018)

Internet 5: The United Nations Institute for Training and Research https://unitar.org/unosat/ (07.04.2018)

Internet 6: Iranian Seismological Center http://irsc.ut.ac.ir (28.02.2018)

Internet 7: The Fars News http://www.farsnews.com (15.01.2018)

International Institute of Earthquake Engineering and Seismology IIEES. (2017). Report on 12th November 2017, magnitude 7.3 earthquake in Sarpol-e Zahab, Kermanshah Province, 5rd Edition, Tehran, Iran (in Persian)

Legget, R.F. (1980). What Every City Should do about Geology and its Underground. Underground Space, 4(5), 273-277.

Lollino, G., A. Manconi, J. Clague, W. Shan, and M. Chiarle (2015). Engineering Geology for Society and Territory - Volume 5, Urban Geology, Sustainable Planning and Landscape Exploitation. Springer International Publishing Switzerland.

Marschalko, M., I. Yilmaz, M. Bednarik, and K. Kubečka (2013). Identification of the near-surface geological structure and deposits for land use planning purposes in the Doubrava Region (Czech Republic). Episodes, 36, 94-104.

Mathewson, C.C. and R.G. Font (1974). The Geological Environment - Forgotten aspect in landuse planning process, in H.F. Ferguson (eds.), Engineering Geology Case Histories, No. 10,., GSA, p23-28.

McGill, J. (1964). Growing importance of urban geology. USGS Publications Warehouse, http://pubs.er.usgs.gov/publication/ cir487

Miyajima, M., A. Fallahi, T. Ikemoto, M. Samaei, S. Karamzadeh, H. Setiawan, F. Talebi, and J. Karashi (2018). Site Investigation of the Sarpole-Zahab Earthquake, Mw 7.3 in SW Iran of November 12, 2017. JSCE Journal of Disaster FactSheets, 2018-E-0002.

NATIONAL IRANIAN OIL COMPANY, NIOC. (2013). Sarpol-e Zahab 1:50,000 Geological map, sheet No. 5158I.

Pantelias, E., A.D. Zervakou, P.I.Tsombos, and K.G. Nikolakopoulos (2008). Spatial database for the management of urban geology geothematic information: the case of Drama City, Greece. Remote Sensing for Environmental Monitoring, GIS Applications, and Geology VIII, https://doi.org/10.1117/12.798864

Price, D.G. (1971). Engineering Geology in the Urban Environment. Quarterly Journal of Engineering Geology and Hydrogeology, 4, 
191-208. https://doi.org/10.1144/ GSL.QJEG.1971.004.03.03

Road, Housing and Urban Development Research Center, BHRC. (2017). Immediate-preliminary report on 12th November 2017, earthquake in Sarpol-e Zahab, Kermanshah Province, Tehran, Iran (in Persian).

Sarvar, R. (2009). An Introduction to the Foresight of the Expansion of Informal Settlements in the Urban Area of Tehran. Hafteshahr, 29-30 (in Persian).

Viles, H.A. (2013). Durability and conservation of stone: coping with complexity. Quarterly Journal of Engineering Geology and Hydrogeology, 46, 367-375. https://doi.org/10.1144/ qjegh2012-053

Zamani, A., and M. Agh-Atabai (2011). Multifractal analysis of the spatial distribution of earthquake epicenters in the Zagros and Alborz-Kopeh Dagh regions of Iran. J Sci Technol, A1, 39-51. 